\title{
“INFLUENCE OF CHEMICAL PRESERVATIVES AND PASTEURIZATION TEMPERATURE ON PRESERVATION OF CUSTARD APPLE PULP IN DEEP FREEZER"
}

\section{SWETHA M. J, LAXMAN KUKANOOR \& MANJULA KARADIGUDDI}

Department of Post Harvest Technology, K. R. C. College of Horticulture, Arabhavi, Karnataka, India

An attempt was made to study the combination treatment of chemical preservative and pasteurization treatment, to preserve the custard apple pulp in deep freezer for a period of three months. The results revealed that chemical constituents of the pulp viz., total soluble solids, reducing sugar, total sugars and non enzymatic browning were found to increased marginally from 26.54 to 27.33 per cent, 15.73 to 15.99 per cent, 19.06 to 19.40 and 1.18 to 1.63 and 0.087 to 0.129 respectively, whereas ascorbic acid, titratable acidity, non-reducing sugar, decreased from 9.38 to $7.95 \mathrm{mg}$ per $100 \mathrm{~g}, 0.69$ to 0.50 per cent, 3.11 to 3.02 per cent, 41.17 to 36.32 and 5.35 to 5.04 respectively, during the storage period of 90 days. However, non significant differences were noticed in total sugar throughout the storage period, for acidity at 30, 60 and 90 days and for non reducing sugar at 30 and 90 days after storage. During storage period of 90 days, the mean organoleptic scores decreased from an 8.14 to 5.91 for overall acceptability. There was marginal increase in microbial load $(T B C)$ in custard apple pulp during storage, but it did not affect the wholesomeness of the product up to 90 days of storage.

KEYWORDS: Pasteurization, Potassium Metabisulphate, Ascorbic Acid, Browning, Microbial Load \& Peroxidase Enzyme
\end{abstract}

Received: Mar 30, 2017; Accepted: Apr 27, 2017; Published: May 24, 2017; Paper Id.: IJASRJUN201726

\section{INTRODUCTION}

Custard apple (Annona squamosa L.), is one of the important dry land fruit which belong to genus Annona of the family Annonaceae, which is indigenous to tropical America and have been distributed in tropical, sub tropical and arid zones of the world. This fruit is sometimes considered as poor man's rich food in the arid zones of India. In India, an estimated area and production of custard apple is 20,000 ha and 1.36 lakh tons respectively (Anon, 2012-13). It is grown in Maharashtra, Andhra Pradesh, Karnataka, Punjab, Rajasthan, Uttar Pradesh, Madhya Pradesh, Bihar, West Bengal, Assam, Gujarat, Kerala and Tamil Nadu. Harvesting may extend from August to November depending on the period of flowering. The fruits are harvested in firm condition when the skin between the segments turns to creamy yellow (Aziz and Yusof, 1994).

Custard apple is highly valued for its nutritive qualities. Fruit contains moisture $(70.5 \%)$, carbohydrates $(23.5 \%)$, proteins $(1.6 \%)$, fat $(0.4 \%)$, mineral matter $(0.9 \%)$, iron $(1.0 \%)$, calcium $(0.2 \%)$, phosphorus $(0.04 \%)$ and energy value $104 \mathrm{Kcal} / 100 \mathrm{~g}$ of the edible portion (Gopalan et al., 2004). The edible portion of the fruit varies from 28-37 per cent of the total fruit weight and seeds correspond to 23-40 per cent (Kumhar et al., 2014). Fruit is having TSS of $26.4^{0} \mathrm{~B}$, pH 5.5 and tannins 0.5 per cent (Nanjundaswamy and Mahadevaiah, 1990). In India, post harvest losses of fruits account for five to eighteen per cent at different stages viz., harvesting, handling, 
transporting, storage and marketing of fresh produce. This is a great handicap in exploiting the full potential of this crop area expansion and in increasing their production. The shelf life of fruits can be improved by slowing down the biochemical processes during storage by various treatments or can be converted into value added products. Pulp extraction from the fruit should be done as rapidly as possible, so as to minimize oxidation of the pulp by naturally occurring enzymes. Custard apple pulp when exposed to air turns pink due to peroxide activity and becomes bitter when heated above $55^{\circ} \mathrm{C}$, which renders preservation by heat treatment inapplicable.

Custard apple has a very limited shelf life of just two to three days and is generally eaten fresh after ripening. The development of processing technology will help in better utilization of custard apple fruits through value added product preparation, which may avoid a glut of fresh fruit in the market and make its availability for a longer period. Therefore, in order to explore the possibilities of utilizing the custard apple fruits for processing, an attempt was made to find out the suitable methods of preservation of custard apple pulp by combination treatment of chemical preservatives and pasteurization temperature.

\section{MATERIAL AND METHODS}

The present investigation was carried out during 2015-16 in the Department of Post Harvest Technology, Kittur Rani Channamma College of Horticulture Arabhavi, Belgium district, Karnataka. The experiment was carried out by adopting Completely Randomized Design (CRD) with 7 treatments and 3 replications.

\section{Treatment Details}

- $\quad \mathbf{T}_{1}$ : Potassium met bisulphate $1000 \mathrm{ppm}+$ Pasteurization at $85^{\circ} \mathrm{C}$ for $25 \mathrm{~min}$

- $\quad \mathbf{T}_{2}$ : Potassium met bisulphate $1500 \mathrm{ppm}+$ Pasteurization at $85^{\circ} \mathrm{C}$ for $25 \mathrm{~min}$

- $\quad \mathbf{T}_{3}$ : Ascorbic acid $1500 \mathrm{ppm}+$ Pasteurization at $85^{\circ} \mathrm{C}$ for $25 \mathrm{~min}$

- $\quad \mathbf{T}_{\mathbf{4}}$ : Potassium met bisulphate $1000 \mathrm{ppm}+$ Pasteurization at $90^{\circ} \mathrm{C}$ for $25 \mathrm{~min}$

- $\quad \mathbf{T}_{5}$ : Potassium met bisulphate $1500 \mathrm{ppm}+$ Pasteurization at $90^{\circ} \mathrm{C}$ for $25 \mathrm{~min}$

- $\quad \mathbf{T}_{\mathbf{6}}$ : Ascorbic acid $1500 \mathrm{ppm}+$ Pasteurization at $90^{\circ} \mathrm{C}$ for $25 \mathrm{~min}$;

- $\quad \mathbf{T}_{7}:$ Control

\section{Preparation of Custard Apple Pulp}

Selected fruits are cut into 2 halves and scooped out the pulp with a stainless steel spoon and pulp was extracted using paper. The fine pulp obtained was having the Total Soluble Solids (TSS) of $26^{0}$ Brix and this pulp was used for both the experiments on standardization of combination of preservatives and pasteurization treatment. After preparation preservatives were added, pulp was bottled and pasteurized as per the treatment details to the pulp. After pasteurization the bottles were cooled and kept in storage in deep freezer where temperature maintained was $-20 \pm 5^{\circ} \mathrm{C}$ for three months.

Total Soluble Solids $\left({ }^{0} \mathbf{B}\right)$

The total soluble solids of custard apple pulp were measured by using an 'Erma' make hand refractometer, and expressed as percentage after making necessary corrections. 


\section{Titratable Acidity (\%)}

A known volume of sample $(5 \mathrm{ml})$ was taken and titrated against the standard $\mathrm{NaOH}$ using phenolphthalein indicator. The appearance of light pink color was marked as the end point. The value was expressed in terms of citric acid as per cent titratable acidity of pulp and powder (Anon., 1984).

$$
\text { Acidity }(\%)=\frac{\text { Titre value } \times \mathrm{N} \text {. Of } \mathrm{NaOH} \times \text { Vol. made up } \times \text { Eq. weight of acid }}{\text { Vol. of the sample } \times \text { Weight or vol. of sample taken } \times 1000} \times 100
$$

\section{Ascorbic Acid (mg/100g)}

Ascorbic acid content was estimated by using 2, 6- Dichlorophenol indophenols dye titrimetrically as per the modified procedure of AOAC (Anon., 1984). The five ml sample was taken and diluted to the known volume (100 ml) with 4 per cent oxalic acid. This was filtered through muslin cloth to get clear juice. Five ml of aliquot was titrated against 2, 6- dichlorophenol indophenol dye till the pink end point which persisted for at least 15 seconds. The results were expressed as milligrams of ascorbic acid per $100 \mathrm{ml}$

$$
\text { Ascorbic acid }(\mathrm{mg} / 100 \mathrm{~g})=\frac{\text { Dye factor } \times \text { Titre value } \times \text { Vol. made up }}{\text { Aliquot } \times \text { Vol.of sample }} \times 100
$$

Sugars (\%)

The sugar content of the pulp obtained from a representative sample under each treatment was estimated and expressed in percentage.

\section{Reducing Sugar (\%)}

Reducing sugar in the sample was estimated as per the Dinitrosalicylic acid method (Miller, 1972). The values obtained were expressed in percentage.

\section{Total Sugars $(\%)$}

The total sugars present in the fruit pulp were estimated by the same method, as in the case of reducing sugar after inversion of the non-reducing sugars using dilute hydrochloric acid (Anon., 1984). One ml of evaporated extract was taken and kept in boiling water bath, till the alcohol completely evaporated and allowed it to cool. Then, phenolphthalein indicator was added, followed by $1 \mathrm{~N}$ sodium hydroxide, till the solution turned to pink. Again, $0.1 \mathrm{~N}$ hydrochloric acid was added to discolor the solution. Then Dinitro-salicylic acid (DNSA) method for reducing sugar was followed. The results obtained were expressed in terms of percentage

\section{Non-reducing Sugars $(\%)$}

The percent non-reducing sugars were obtained by subtracting the value of reducing sugar from that of total sugar and multiplied by a 0.95 correction factor.

Non-reducing sugar $(\%)=[$ Total sugar $(\%)-$ Reducing sugar $(\%)] \times 0.95$

\section{Non-enzymatic Browning (OD value)}

The analysis for browning for custard apple pulp was carried out. For semi-solids and solid foods like pulp and powder, $10 \mathrm{~g}$ of the sample was taken and blended; this blended sample was added with $10 \mathrm{ml}$ of distilled water and $30 \mathrm{ml}$ of 60 per cent alcohol. This mixture was mixed thoroughly and filtered through watman No. 1 filter paper. Measure the 
absorbance of the sample at 440nm for non-enzymatic browning. Prepare 60 percent ethyl alcohol solution as blank.

\section{Microbial Analysis (CFU/g)}

The microbial analysis of custard apple pulp was carried out as per the method of Harrigan and Mccance (1966). Ten $\mathrm{ml}$ of juice was taken for analysis. The samples were placed on nutrient agar media for bacterial isolation following serial dilution technique. Plates were incubated for two days at $28 \pm 1^{0} \mathrm{C}$ and colonies were counted and CFU per $\mathrm{g}$ was calculated.

\section{Organoleptic Evaluation (Score Out of 9.00)}

Organoleptic evaluation of custard apple pulp and powder was carried out by a panel of 10 semi-trained judges. The organoleptic characters like color and appearance, flavor/texture, taste, and overall acceptability were evaluated on a 9 point Hedonic scale using the scorecard mentioned below

\section{RESULTS AND DISCUSSIONS}

It was observed from the analysis (Table 1), the acidity of preserved pulp was found significant during initial days of storage (DAS) and was found to be no significant during 30, 60 and 90 days of its storage period. Among the treatments, $\mathrm{T}_{3}$ has recorded highest acidity of $0.79 \%$, and it was found to decrease during the storage period. This might be due to chemical reaction between the organic constituents of the pulp, and influenced further by temperature and enzymatic action. Ascorbic acid was found highest in treatment $\mathrm{T}_{3}$ during initial to $90 \mathrm{DAS}$, and was found to decrease during the storage period. This behavior may be due to its oxidation by trapping oxygen in the glass bottles, which results in formation of dehydroascorbic acid pulp. TSS of the stored pulp was found to be highest in treatment $\mathrm{T}_{7}$ during the initial days and with respect to 30,60 and $90 \mathrm{DAS} \mathrm{T}_{3}$ has recorded highest, TSS has shown an increasing trend during the storage period.

Highest reducing sugar was found in treatment $T_{3}$ and was found to be significant during initial, 30, 60 and 90 DAS, whereas with respect to non reducing sugars, it was found to be significant during initial, 30, 90 DAS, but was non significant during 60 DAS. Highest non reducing sugar was found in treatment $T_{7}$ and has shown a decreasing trend with respect all treatments during the storage period. Total sugars did not show any significant differences among the treatments at fresh, as well as during the storage period. Total sugars and reducing sugars was found to increase during the storage period, this increase corresponds to decrease in non-reducing sugars, which might ne due to hydrolysis of polysaccharides into reducing sugars during storage. Similar observations have been made by Kavya (2014) in custard apple, Pawar et al. (2010) in custard apple.

Non enzymatic browning showed an increasing trend in the browning value during the period of storage. The minimum score for non enzymatic browning was recorded in treatment $\mathrm{T}_{4}$ during 90 DAS which might be due to effective control of enzymatic browning by potassium metabisulphite and pasteurization treatments. The quality of the custard apple pulp may deteriorate during storage. The microbial population showed a slight increase in number during storage period of 90 days. The treatment $T_{7}$ has recorded highest microbial load compare to other treatments as it was not treated with KMS, ascorbic acid and was not pasteurized. The least microbial load was recorded for treatment T3, which might be due to the effect of heat treatment which has killed the microorganisms and hence the less number of microorganisms was found. The results corroborate with Kavya (2014) in custard apple pulp. It is known fact that the quality of the stored food products such as color, taste, flavor and nutritive value was generally reduced with the increase in storage period. In the present 
study also, organoleptic score of the pulp decreased in all the treatments as the storage period has increased. Similar decreases in sensory quality during storage of the pulp has been reported by Gamage et al. (1997) in custard apple, Sonia et al. (2003) in sand pear, Hashmi et al. (2007) in mango pulp, Akhtar et al. (2009) in mango, Durrani et al. (2010) in apple pulp, Kamble and Soni (2010) in custard apple pulp.

Custard apple is a seasonal fruit, which has very limited shelf life of just two or three days, and it is generally eaten fresh after ripening. The preservation of pulp helps in the better utilization of custard apple through various value added product preparation. Hence, in order to utilize the full potentiality of the crop can experiment regarding preservation of pulp was carried out, custard apple pulp treated with ascorbic acid $1500 \mathrm{ppm}+$ pasteurization at $85^{0} \mathrm{C}$ for 25 minutes $\left(\mathrm{T}_{3}\right)$ had scored better result with respect to physical-chemical characters and organoleptic traits, followed by potassium metabisulphate $1000 \mathrm{ppm}+$ pasteurization at $85^{\circ} \mathrm{C}\left(\mathrm{T}_{1}\right)$, up to three months of storage, when kept in deep freezer.

\section{REFERENCES}

1. ANONYMOUS., 1984, Official Methods of Analysis. Ed. Sidney Williams, Association official Analytical Virginia. $14^{\text {th }}$ edition, pp. 424- 462.

2. ANONYMOUS., 2012-13, Dept. of agri. and cooperation, Horti. Division.

3. AKHTAR, S., MAHMOOD, S., NAZ, S., NASIR, M. AND SULTAN. M. T., 2009, Sensory evaluation of mangoes (Mangiferaindica. L) grown in different regions of Pakistan. Pak. J. of Bot., 41(6): 2821-2829.

4. AZIZ, P. A. AND YUSOF, S., 1994, Physico chemical characteristics of soursop fruit (Annona muricata) during growth and development. Asian Food J., 9(4):147-150.

5. DURRAni, Y., AYUB, M., MUhammaD, A. AND ALI, A., 2010, Physic-chemical response of apple pulp to chemical preservatives and antioxidant during storage. J. of Food Safety., 12: 20-28.

6. GAMAGE, T. V., YUEN, C. M. AND WILLS, R. B. H., 1997, Minimal processing of custard apple (Annona atemoya) pulp. J. Process. Preservation., 21: 289-301.

7. GOPALAN, C., KADAM, S. S. AND SIVASANKAR, B., 2004, Nutritive value of Indian food, National Institute of Nutrition, Indian council of medical research, Hyderabad.

8. HARRIGAN, W. F. AND MCCANCE, M. E., 1966, Laboratory methods in Microbiology. Academic press, London, pp. 14-16.

9. HASHMI, M. S., ALAM, S., RIAZ, A. AND SHAH, A. S., 2007, Studies on microbial and sensory quality of mango pulp storage with chemical preservatives. Pak. J. Nutri. 6 (1): 85-88.

10. KAMBLE, K. J. AND SONI, S. B., 2010, Effect of steam blanching on quality of custard apple pulp. J. Hort. For., 2(5): 104107.

11. KAVYA, D., 2014, Studies on processing and preservation of custard apple pulp, squash and ready to serve bevarages. M. Sc. (Hort.) Thesis submitted to Univ. Hort. Sci. Bagalkot.

12. KUMHAR, D. S., PAREEK, S. AND AMETA, K. D., 2014, Effect of antioxidants and storage temperatures on browning and quality of custard apple (Annona squamosa L.) pulp. J. Sci. Ind. Res., 73: 622-626.

13. PANSE, V. S. AND SUKHATME, P. V., 1967, Statistical methods for agricultural workers. Indian Council of Agricultural Research, New Delhi, pp. 152-174. 
14. PAWAR, V. N., KARDILE, W. G. AND HASMI, S. H., 2010, Studies on inactivation profile of polyphenol oxidase (PPO) from custard apple (Annona squamosa L.) pulp by heat treatment and its effects on sensorial quality. Food Sci. Res. J., 1(2):137141.

15. SONIA, S., SOGI, D. S. AND BAWA, A. S., 2003, Shelf-life studies on chemically preserved sand pear (Pyrus pyrifolia cv. Patharnakh) pulp. J. Food Sci. Technol., 40: 230-232.

\section{APPENDICES}

Table 1: Effect of Treatments on Titratable Acidity (\%), Ascorbic Acid $(\mathrm{mg} / 100 \mathrm{~g})$ and TSS $\left({ }^{0} \mathrm{~B}\right)$ of Custard Apple Pulp during Storage

\begin{tabular}{|c|c|c|c|c|c|c|c|c|c|c|c|c|}
\hline \multirow{3}{*}{ Treatments } & \multicolumn{5}{|c|}{ Titratable Acidity (\%) } & \multicolumn{3}{|c|}{ Ascorbic Acid (mg/100g) } & \multicolumn{4}{|c|}{ Total Soluble Solids $\left({ }^{0} \mathrm{~B}\right)$} \\
\hline & \multicolumn{12}{|c|}{ Days after Storage } \\
\hline & Initial & 30 & 60 & 90 & Initial & 30 & 60 & 90 & Initial & 30 & 60 & 90 \\
\hline $\mathrm{T}_{1}$ & 0.68 & 0.63 & 0.60 & 0.50 & 6.90 & 6.85 & 6.51 & 6.22 & 25.70 & 26.17 & 26.76 & 26.87 \\
\hline $\mathrm{T}_{2}$ & 0.65 & 0.60 & 0.57 & 0.47 & 7.43 & 7.00 & 7.01 & 6.46 & 26.87 & 27.33 & 27.74 & 27.33 \\
\hline $\mathrm{T}_{3}$ & 0.79 & 0.74 & 0.67 & 0.57 & 14.50 & 14.26 & 13.32 & 12.52 & 26.77 & 27.50 & 27.94 & 28.24 \\
\hline $\mathrm{T}_{4}$ & 0.68 & 0.66 & 0.63 & 0.49 & 7.63 & 7.06 & 6.67 & 5.39 & 26.50 & 26.80 & 26.93 & 27.27 \\
\hline $\mathrm{T}_{5}$ & 0.67 & 0.62 & 0.59 & 0.47 & 7.40 & 7.06 & 6.86 & 5.16 & 26.50 & 26.77 & 26.93 & 27.13 \\
\hline $\mathrm{T}_{6}$ & 0.75 & 0.71 & 0.67 & 0.53 & 14.36 & 14.13 & 13.16 & 12.03 & 26.50 & 26.65 & 26.93 & 27.20 \\
\hline $\mathrm{T}_{7}$ & 0.59 & 0.57 & $*$ & $*$ & 7.50 & 5.46 & $*$ & $*$ & 27.00 & 27.30 & $*$ & $*$ \\
\hline Mean & 0.69 & 0.65 & 0.62 & 0.51 & 9.38 & 8.83 & 8.91 & 7.95 & 26.54 & 26.93 & 27.20 & 27.33 \\
\hline S.Em \pm & 0.03 & 0.02 & 0.05 & 0.05 & 0.34 & 0.43 & 0.33 & 0.44 & 0.39 & 0.16 & 0.09 & 0.08 \\
\hline C.D. @ 1\% & 0.12 & NS & $\mathrm{NS}$ & NS & 1.43 & 1.82 & 1.43 & 1.85 & $\mathrm{NS}$ & 0.72 & 0.38 & 0.30 \\
\hline
\end{tabular}

Table 2: Effect of Treatments on Reducing Sugars (\%), Non Reducing Sugars

$(\%)$ and Total Sugars (\%) of Custard Apple Pulp during Storage

\begin{tabular}{|c|c|c|c|c|c|c|c|c|c|c|c|c|}
\hline \multirow{3}{*}{ Treatments } & \multicolumn{4}{|c|}{ Reducing Sugars } & \multicolumn{4}{|c|}{ Non Reducing Sugars } & \multicolumn{4}{|c|}{ Total Sugars } \\
\hline & \multicolumn{12}{|c|}{ Days after Storage } \\
\hline & Initial & 30 & 60 & 90 & Initial & 30 & 60 & 90 & Initial & 30 & 60 & 90 \\
\hline $\mathrm{T}_{1}$ & 15.87 & 15.90 & 15.93 & 16.02 & 3.07 & 3.05 & 3.04 & 3.03 & 19.06 & 19.17 & 19.29 & 19.35 \\
\hline $\mathrm{T}_{2}$ & 15.86 & 15.91 & 15.93 & 15.70 & 3.13 & 3.12 & 3.11 & 3.10 & 19.15 & 19.30 & 19.41 & 19.49 \\
\hline $\mathrm{T}_{3}$ & 15.89 & 16.29 & 16.32 & 16.36 & 2.65 & 2.64 & 2.63 & 2.57 & 19.03 & 19.23 & 19.30 & 19.38 \\
\hline $\mathrm{T}_{4}$ & 15.80 & 15.88 & 15.94 & 15.98 & 3.07 & 3.07 & 3.01 & 3.00 & 19.04 & 19.27 & 19.32 & 19.41 \\
\hline $\mathrm{T}_{5}$ & 15.49 & 15.52 & 15.60 & 16.23 & 3.39 & 3.36 & 3.31 & 3.04 & 19.06 & 19.16 & 19.29 & 19.43 \\
\hline $\mathrm{T}_{6}$ & 15.88 & 15.90 & 15.94 & 15.98 & 3.04 & 3.03 & 3.01 & 3.00 & 19.08 & 19.19 & 19.29 & 19.42 \\
\hline $\mathrm{T}_{7}$ & 15.38 & 15.51 & $*$ & $*$ & 3.44 & 3.41 & $*$ & $*$ & 19.01 & 19.10 & $*$ & $*$ \\
\hline Mean & 15.73 & 15.84 & 15.94 & 16.04 & 3.11 & 3.09 & 3.01 & 2.95 & 19.06 & 19.20 & 19.31 & 19.41 \\
\hline S.Em \pm & 0.10 & 0.11 & 0.14 & 0.12 & 0.05 & 0.04 & 0.22 & 0.06 & 0.12 & 0.09 & 0.07 & 0.05 \\
\hline C.D. @ 1\% & 0.45 & 0.44 & 0.45 & 0.46 & 0.15 & 0.13 & $\mathrm{NS}$ & 0.29 & NS & NS & NS & NS \\
\hline
\end{tabular}

Table 3: Effect of Treatments on Non Enzymatic Browning (OD Value), Total Bacterial Count (CFU/ml) and Overall Acceptability of Custard Apple Pulp during Storage

\begin{tabular}{|c|c|c|c|c|c|c|c|c|c|c|c|c|}
\hline \multirow{3}{*}{ Treatments } & \multicolumn{5}{|c|}{ Non Enzymatic Browning } & \multicolumn{3}{|c|}{ Total Bacterial Count } & \multicolumn{4}{|c|}{ Overall Acceptability } \\
\hline & \multicolumn{12}{|c|}{ Days after Storage } \\
\hline & Initial & 30 & 60 & 90 & Initial & 30 & 60 & 90 & Initial & 30 & 60 & 90 \\
\hline $\mathrm{T}_{1}$ & 0.043 & 0.055 & 0.073 & 0.093 & 31.33 & 46.67 & 64.00 & 66.00 & 8.50 & 8.00 & 7.25 & 7.00 \\
\hline $\mathrm{T}_{2}$ & 0.044 & 0.054 & 0.072 & 0.086 & 24.67 & 33.67 & 43.00 & 47.33 & 8.00 & 7.83 & 7.00 & 6.33 \\
\hline $\mathrm{T}_{3}$ & 0.138 & 0.154 & 0.159 & 0.167 & 17.00 & 30.00 & 39.33 & 41.67 & 8.67 & 8.63 & 7.50 & 7.50 \\
\hline $\mathrm{T}_{4}$ & 0.043 & 0.054 & 0.061 & 0.066 & 28.67 & 36.33 & 46.00 & 49.33 & 8.00 & 7.83 & 6.50 & 7.17 \\
\hline $\mathrm{T}_{5}$ & 0.054 & 0.066 & 0.082 & 0.090 & 26.33 & 38.33 & 43.67 & 44.67 & 7.83 & 7.83 & 7.33 & 6.17 \\
\hline $\mathrm{T}_{6}$ & 0.132 & 0.148 & 0.161 & 0.187 & 23.67 & 35.33 & 54.00 & 55.33 & 8.67 & 8.50 & 7.33 & 7.17 \\
\hline $\mathrm{T}_{7}$ & 0.158 & 0.177 & $*$ & $*$ & 60.00 & 71.67 & $*$ & $*$ & 7.33 & 6.17 & $*$ & $*$ \\
\hline Mean & 0.087 & 0.101 & 0.101 & 0.114 & 30.24 & 41.71 & 48.33 & 50.72 & 8.14 & 7.83 & 6.13 & 5.91 \\
\hline S.Em \pm & 0.028 & 0.007 & 0.005 & 0.004 & 1.90 & 2.64 & 4.44 & 3.82 & 0.19 & 0.29 & 0.24 & 0.14 \\
\hline C.D. @ 1\% & 0.011 & 0.025 & 0.018 & 0.013 & 7.99 & 11.11 & 18.69 & 16.07 & 0.68 & 0.91 & NS & NS \\
\hline
\end{tabular}

